\title{
THEMATIC BASED PRIVATE VOCATIONAL SCHOOL LEARNING CHOMPARISON ANALYSIS IN ONE SHEET LESSON PLAN
}

\author{
Moh. Imam sufiyanto \\ Institut Agama Islam Negeri (IAIN) MADURA \\ bersamabiologi@gmail.com

\section{Roviandri} \\ Institut Agama Islam Negeri (IAIN) MADURA \\ andrearavipotter@gmail.com
}

\begin{abstract}
The existence of new policies in the field of education is often interpreted as having changed the curriculum even though this is a common thing. The point is how learning practices in schools will become better, more efficient, and more effective. Likewise with the policy of drafting a one-sheet RPP which was initiated the Minister of Education and Culture to help reduce the burden on teachers in the field implementing learning. In simple terms, actually several RPP pages that previously could be summarized/abstracted into just one-sheet, then select the components that are considered core and must exist. There are also other components that can be attached or even removed, because it could be implied and expressed in the existing core components. However, for prospective teachers, it is better if they continue to study the lesson plans with the full component version and then learn to abstract into one-sheet RPP.
\end{abstract}

Keywords: RPP, RPP one-sheet, RPP Social Studies Subject.

\begin{abstract}
Abstrak
Adanya kebijakan baru di bidang pendidikan seringkali diartikan sebagai telah merubah kurikulum padahal hal tersebut merupakan hal yang lumrah. Intinya adalah bagaimana praktik pembelajaran di sekolah menjadi lebih baik, lebih efisien, dan lebih efektif. Begitu pula dengan kebijakan penyusunan RPP satu lembar yang digagas oleh Menteri Pendidikan dan Kebudayaan untuk membantu mengurangi beban guru di bidang penyelenggaraan pembelajaran. Secara sederhana, sebenarnya beberapa halaman RPP yang sebelumnya dapat diringkas/disarikan menjadi satu lembar saja, kemudian dipilih komponen-komponen yang dianggap inti dan harus ada. Ada juga komponen lain yang bisa dipasang atau bahkan dilepas, karena bisa tersirat dan terekspresikan dalam komponen inti yang ada. Namun bagi calon guru, ada baiknya jika tetap mempelajari RPP dengan versi komponen lengkap kemudian belajar mengabstraksi menjadi RPP satu lembar.
\end{abstract}

Kata kunci: RPP, RPP satu lembar, RPP Mata Pelajaran IPS

Program Studi Pendidikan Guru Madrasah Ibtidaiyah

STAI Al-Azhar Menganti Gresik, Indonesia

\section{Pendahuluan}

Kebijakan membuat Rencana Pelaksanaan Pembelajaran satu lembar merupakan upaya penyederhanaan skenario pembelajaran yang dibuat oleh guru sebelumnya yang isinya banyak lembar, jika dihitung lembaran mulai dari identitas sampai dengan rubrik penilaian 
ZAHRA: Research And Tought Elmentary School Of Islam Journal Vol. (2) (2), (Agustus)(2021), (Halaman)(123-133)| 124 boleh jadi lebih dari 10 lembar.Hal inilah yang dianggap terlalu memberatkan guru dalam mempersiapkannya. Untuk itu, penyederhanaan dilakukan dengan hanya mencantumkan tujuan pembelajaran, langkah-langkah pembelajaran dan penilaian. Dari sebelumnya mencantumkan identitas sekolah, identitas mata pelajaran, KI dan KD, indikator, tujuan pembelajaran, materi, metode pembelajaran, media dan sumber belajar, langkah-langkah pembelajaran, penilaian hingga lengkap dengan rubriknya; bahkan juga diperlukan lampiran rubrik penilaian dan bahan ajar.

Berkaitan dengan RPP Mata Pelajaran Ilmu Pengetahuan Sosial (IPS), hal yang perlu diperhatikan adalah adanya tema dan subtema yang menjadi pengikat berbagai konsep yang ada dalam mata pelajaran tersebut. Rencana Pembelajaran inilah sebagai suatu implikasi dari pada matapelajaran IPS yang terbentuk dari perpaduan dari berbagai konsep dari disiplin ilmuSosial, seperti: konsep dalam ilmu Ekonomi, Sejarah, Sosiologi, Geografi, Pendidikan, Antropologi, Politik dan sebagainya. Pada proses pembelajaran dimasa pandemi, model pembelajaran yang diterapkan seharusnya juga model pembelajaran terpadu. Ciri dari keterpaduan ini adalah adanya tema/subtema yang berfungsi untuk mengikat konsep-konsep dari berbagai disiplin ilmu sosial. Keterpaduan dalam tema/subtema minimal terdiri atas dua konsep disiplin ilmu dari ilmu sosial yang dikaitkan/dipadukan.

Geografi, sejarah, dan antropologi merupakan disiplin ilmu yang memiliki keterpaduan yang tinggi. Pembelajaran geografi memberikan kebulatan wawasan yang berkenaan dengan wilayah-wilayah, Adapun sejarah memberikan wawasan berkenaan dengan peristiwa peristiwa dari berbagai periode, antropologi meliputi studi studi komparatif yang berkenaan dengan nilai-nilai, kepercayaan, struktur sosial, aktivitas aktivitas ekonomi, organisasi politik, ekspresi-ekspresi dan spiritual, teknologi, dan benda-benda budaya dari budaya-budaya terpilih.

Ilmu politik dan ekonomi tergolong ke dalam ilmu-ilmu tentang kebijakan pada aktivitas-aktivitas yang berkenaan dengan pembuatan keputusan. Sosiologi dan psikologi sosial merupakan ilmu-ilmu tentang perilaku seperti konsep peran, kelompok, institusi, proses interaksi dan kontrol sosial secara intensif konsep-konsep seperti ini digunakan ilmuilmu sosial dan studi sosial. Sehingga dalam memahami konsep-konsep ilmu sosial yang cangkupan ilmunya luas dapat dikaji dalam rencana pelaksanaan pembelajaran (RPP) dengan terstruktur dan mudah dipahami baik oleh guru maupun siswa sekolah dasar (SD) yang disajikan dalam pembelajaran ilmu sosial. Pada penelitian sebelumnya dijelaskan bahwa model-model pembelajaran IPS dengan konsep talking stick juga memuat unsur-unsur ilmu sosial(Munchen, 2018), Dalam strategi pembelajaran IPS keberagaman rumpun ilmu menjadi 
ZAHRA: Research And Tought Elmentary School Of Islam Journal Vol. (2) (2), (Agustus)(2021), (Halaman)(123-133)| 125 prioritas untuk kajian RPP yang akan disusun sesuai dengan konsep ilmu sosial (Saharuddin, 2020), serta dalam penerapan RPP satu lembar dapat dikelompokkan kedalam MGMP dalam rumpun ilmu-ilmu sosial agar RPP yang disusun sesuai strategi dan rencana pembelajaran (Gunawan \& Asrifan, 2020).

Berkaitan dengan beberapa penelitian terdahulu, yang dapat berjalan selaras dengan berbagai penelitian yang telah dilaksanakan sebelumnya berkaitan dengan "Implementasi Pembelajaran Tematik pada siswa kelas rendah SD Negeri Balekerto Kecamatan Kaliangkrik" dengan hasil penelitiananya menunjukkan bahwa tahap perencanaan pembelajaran masih variatif, belum semua menggunakan dan mengaplikasikan model RPP tematik dan ada pula sebagian yang sudah menggunakan dan mengaplikasikan model RPP tematik dengan hambatan terbesarnya adalah kurangnya sosialisasi mengenai pembelajaran tematikpun juga demikian penelitian dengan judul "Pengaruh implementasi pendekatan tematik terhadap peningkatan pemahaman konsep dan kreativitas siswa dalam pembelajaran Ilmu Pengetahuan Sosial" berkesimpulan bahwa Implementasi pendekatan pembelajaran tematik berpengaruh secara signifikan terhadap peningkatan pemahaman konsep siswa dalam pembelajaran IPS SD serta peningkatan kreativitas siswa sebagai dampak atas implementasi pembejaran tematik masih terbatas pada tahap, tingkat dan derajat kreativitas tertentu.

\section{Metode Penelitian}

Jenis penelitian yang digunakan pada penelitian kali ini adalah pendekatan kualitatif dengan metode penelitian studi pustaka (library research). Dengan Sumber data yang digunakan bersifat kepustakaan atau berasal dari berbagai literatur, diantaranya buku, jurnal, suat kabar, dokumen pribadi, dan lain sebagainya. Sumber data dalam penelitian ini dibedakan menjadi sumber primer dan sumber sekunder dan lebih menekankan pada RPP 1 lembar yang beredar di internet dan RPP 1 lembar milik Guru SDN Tlambah 2.

Teknik pengumpulan data pada penelitian ini adalah Editing, Organizing, Finding. Dari teknik inilah diharapkan dapat mengumpulkan data-data pada penelitian yang akan dilaksanakan, sehingga dapat dikumpulkan data yang akurat dan mampu dianalisis nantinya. Sedangkan Analisis data dalam penelitian ini menggunakan analisis data komparatif dan historis.Analisis data komparatif yaitu membandingkan objek penelitian dengan konsep pembanding.Dan analisis historis yaitu melakukan analisis kejadian-kejadian dimasa yang lalu untuk mengetahui kenapa dan bagaimana suatu peristiwa itu telah terjadi (Yaniawati, 13-15:2020).

\section{Diskusi}

Prosedur pengumpulan data pada penelitian ini adalah observasi. Observasi atau pengamatan merupakan suatu teknik atau cara mengumpulkan data dengan mengadakan pengamatan terhadap kegiatan yang sedang berlangsung. Observasi dilakukan untuk memperoleh gambaran riil suatu 
ZAHRA: Research And Tought Elmentary School Of Islam Journal Vol. (2) (2), (Agustus)(2021), (Halaman)(123-133)| 126 peristiwa atau kejadian untuk menjawab pertanyaan penelitian. Ada dua teknik pada observasi yaitu observasi partisipan dan observasi non partisipan. Adapun observasi yang dilakukan peneliti termasuk dalam jenis observasi non partisipan. Observasi non partisipan adalah seorang pengamat bisa melakukan pengumpulan data tanpa harus melibatkan diri langsung ke dalam situasi dimana peristiwa itu berlangsung, melainkan dengan menggunakan media tertentu yang ada pada suatu peristiwa dalam proses atau kejaidan, dalam hal ini adalah menganalisis dari Rencana Pelaksanaan Pembelajaran (RPP) pada tingkat satuan Sekolah Dasar (SD) (Ahmadi, 2016:163).

Dalam metode observasi ini tidak hanya mengamati dari segi objek saja melainkan juga membandingkan hal-hal yang terdapat pada objek tersebut, sehingga dapat benar-benar mendapatkan data tentang situasi dan kondisi secara universal dan informan. Adapun informasi yang ingin diperoleh dari hasil obeservasi yaitu perbandingan mengenai Rencana Pelaksanaan Pembelajaran satu lembar yang beredar dilaman internet dengan milik guru SDN Tlambah 2 Kecamatan Karangpenang, Kabupaten Sampang (Herdiansyah, 2013: 58). Dimana dalam membandingkan kedua jenis rencana pelaksanaan pembelajaran yang disusun dianalisis sesuai dengan standart proses yang berlaku dalam peraturan pemerintah sesuai edaran dari kemendikbud, nomor 14 tahun 2019 tentang standar proses yang dijalankan oleh guru dimasa pandemi, karena pada masa pandemi waktu yang diberikan juga sangat singkat untuk menghindari penularan virus covid-19 dan tidak terjadi kluster penularan di sekolah.

Pembelajaran yang disusun sesuai dengan protokol kesehatan (prokes) untuk rencana pelaksanaan pembelajaran ditengah pandemi ini, disusun hanya satu lembar agar memudahkan pelaksanaan pembelajaran dikelas dan waktu yang dibutuhkan lebih efektif, dan efisien sehingga siswa memiliki jam efektif untuk belajar pada pembelajaran IPS yang merupakan pembelajaran yang memiliki rumpun ilmu yang banyak dan membutuhkan penjelasan yang inovatif pada saat pembelajaran berlangsung di kelas.

\section{RPP 1 lembar yang beredar di internet}

RENCANA PELAKSANAAN PEMBELAJARANREVISI 2020

(Disusun Berdasarkan Surat Edaran Mendikbud Nomor: 14 Tahun 2019)

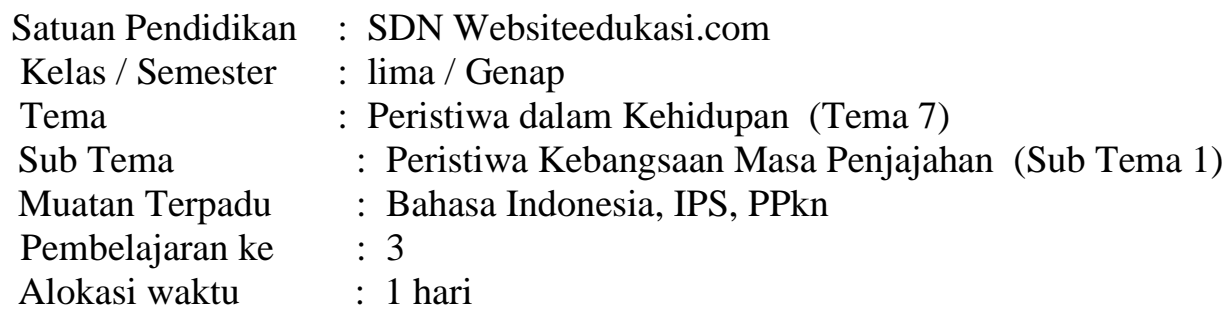

Sumber : https://www.websiteedukasi.com/rpp-kelas-5-tema-7-kurikulum-2013.html Di akses pada tanggal 10 Desember 2020 pukul 17.15 WIB

\section{TUJUAN PEMBELAJARAN}

1. Dengan membaca, siswa dapat menjelaskan sistem tanam paksa pemerintahan kolonial Belanda secara benar.

2. Dengan membaca, siswa dapat menjelaskan berbagai perlawanan terhadap pemerintahan kolonial Belanda di berbagai daerah secara benar. 
3. Dengan bercerita, siswa dapat menyebutkan berbagai keragaman yang ada di sekitarnya secara tepat.

4. Dengan menulis, siswa dapat mengidentifikasi berbagai keragaman suku yang ada di Indonesia secara tepat.

\section{KEGIATAN PEMBELAJARAN}

\begin{tabular}{|c|c|c|}
\hline Kegiatan & Deskripsi Kegiatan & $\begin{array}{l}\text { Alokasi } \\
\text { Waktu }\end{array}$ \\
\hline Pendahuluan & $\begin{array}{l}\text { Melakukan Pembukaan dengan Salam dan Dilanjutkan } \\
\text { Dengan Membaca Doa (Orientasi) } \\
\text { * Mengaitkan Materi Sebelumnya dengan Materi yang akan } \\
\text { dipelajari dan diharapkan dikaitkan dengan pengalaman } \\
\text { peserta didik (Apersepsi) } \\
\text { - Memberikan gambaran tentang manfaat mempelajari } \\
\text { pelajaran yang akan dipelajari dalam kehidupan sehari-hari. } \\
\text { (Motivasi) }\end{array}$ & 10 menit \\
\hline Inti & 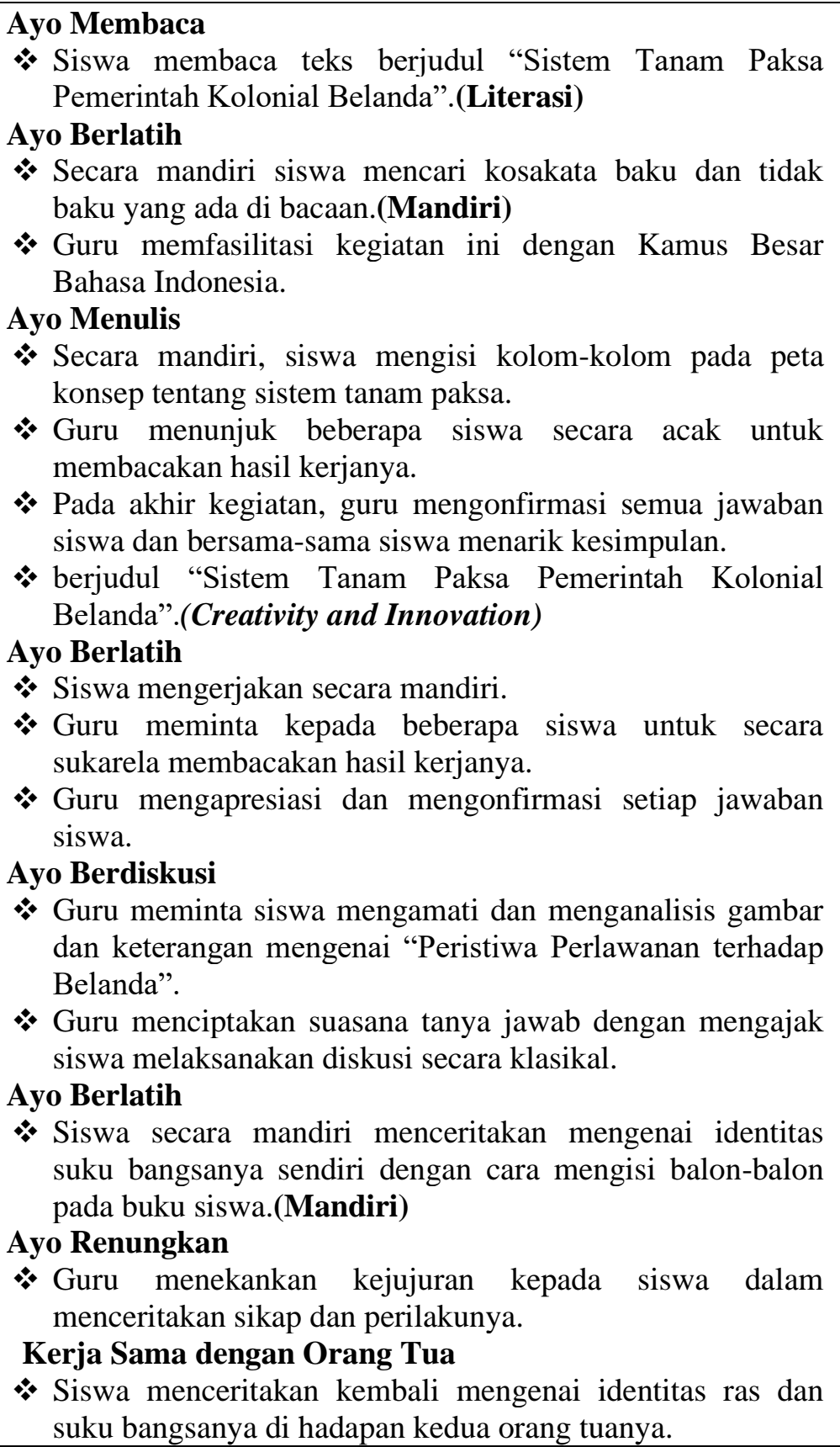 & 150 menit \\
\hline
\end{tabular}


Penutup A. Menyanyikan salah satu lagu daerah untuk menumbuhkan 15 enit Nasionalisme, Persatuan, dan Toleransi.

B. Salam dan do'a penutup di pimpin oleh salah satu siswa. (Religius)

\section{PENILAIAN (ASESMEN)}

Penilaian terhadap materi ini dapat dilakukan sesuai kebutuhan guru yaitu dari pengamatan sikap, tes pengetahuan dan presentasi unjuk kerja atau hasil karya/projek dengan rubrik penilaian

Mengetahui

Kepala Sekolah,

(

NIP
WEBSITEEDUKASI.COM

NIP.
Januari 20.

Guru Kelas 5

2. RPP 1 lembar milik Guru SDN Tlambah 2

\section{RENCANA PELAKSANAAN PEMBELAJARAN \\ (RPP)}

Sekolah
Kelas /Semester
Tema 7
Sub tema 1
Pembelajaran ke-
Fokus Pembelajaran
Alokasi Waktu

:UPTD SDN Tlambah 2

: V/2 (dua)

: Peristiwa dalam Kehidupan

: Peristiwa Kebangsaan Masa Penjajahan

: 3

: Bahasa Indonesia dan IPS.,PPKn

: 6 x 35 menit (6 JP)

\section{TUJUAN PEMBELAJARAN}

1. Dengan membaca, siswa dapat menjelaskan sistem tanam paksapemerintahan kolonial Belanda secara benar.

2. Dengan membaca, siswa dapat menjelaskan berbagai perlawananterhadap pemerintahan kolonial Belanda di berbagai daerah secara benar.

3. Dengan bercerita, siswa dapat menyebutkan berbagai keragaman yangada di sekitarnya secara tepat.

4. Dengan menulis, siswa dapat mengidentifikasi berbagai keragaman sukuyang ada di Indonesia secara tepat.

\section{KEGIATAN PEMBELAJARAN}

\section{Kegiatan Pendahuluan}

a. Kelas dimulai dengan dibuka dengan salam, menanyakan kabar dan kehadiran siswa

b. Kelas dilanjutkan dengan do'a dipimpin oleh salah seorang siswa. (religius).

c. Menyanyikan lagu nasional Guru memberikan penguatan semangat Nasionalisme.

d. Pembiasaan membaca/ menulis/ mendengarkan/ berbicara selama 15-20 menit (literasi)

Kegiatan Inti

a. Guru menjelaskan sekitar materi yang akan dijelaskan

b. Guru membagi siswa menjadi beberapa kelompok

c. Siswa mengamati media pembelajaran tentang materi yang diajarkan

d. Guru mengajak siswa berdiskusi berkaitan tentang materi yang diajarkan

e. Siswa berdiskusi dengan sesama anggota kelompoknya dengan bimbingan guru

f. Masing masing kelompok mempresentasikan hasil kelompoknya di depan kelas

g. Guru memberi penguatan tentang jawaban siswa perwakilan kelompok

h. Bersama guru siswa memajang hasil pekerjaan siswa di papan pajangan 
ZAHRA: Research And Tought Elmentary School Of Islam Journal Vol. (2) (2), (Agustus)(2021), (Halaman)(123-133)| 129

Kegiatan Bersama Orang Tua

a. Pemahaman mengenai materi yang dipelajari kembali oleh siswa di rumah bersama orang tua

\section{Kegiatan Penutup}

a. Siswa mapu mengemukan hasil belajar hari ini

b. Guru memberikan penguatan dan kesimpulan

c. Menyanyikan salah satu lagu daerah nasionalisme

d. Salam dan do'a penutup di pimpin oleh salah satu siswa.

PENILAIAN

Penilaian Sikap : Observasi selama kegiatan berlangsung

Penilaian Pengetahuan

Penilaian Keterampilan

Mengetahui

Kepala UPTD SDN

Tlambah 2

Drs.H NAMIN M.Pd

NIP.196712311987031020
Sampang, 16 Januari 2020

Guru Kelas 5

KAMARIYAH S.Pd SD

NIP.196901022007012026

\section{Hasil Penelitian}

Dalam UU No. 20 tahun 2003 tentang sistem pendidikan nasional disebutkan bahwa pembelajaran adalah proses interaksi peseerta didik dengan pendidik dan sumber belajar pada suatu lingkungan belajar. Sedangkan menurut Hamalik, pembelajaran adalah suatu kombinasi yang tersusun meliputi unsur-unsur dari manusiawi, material, fasilitas, perlengkapan, dan prosedur yang saling mempengaruhi untuk mencapai tujuan pembelajaran yang telah disusun, direncanakan, dan dievaluasi (Hamalik, 2005:57). Berdasarkan definisi diatas, dapat diambil kesimpulan sebagai berikut. Pembelajaran adalah suatu proses interaksi yang terjadi antara pendidik dan peserta didik dalam suatu lingkungan belajar untuk mencapai tujuan belajar. Pembelajaran harus didukung dengan baik oleh semua unsur dalam pembelajaran yang meliputi pendidik, peserta didik, dan juga lingkungan belajar.

Perencanaan adalah suatu kegiatan dalam menyusun langkah-langkah penyelesaian suatu masalah atau pelaksanaan suatu pekerjaan yang terarah pada pencapaian tujuan tertentu.Dalam hal ini perencanaan mencakup rangkaian kegiatan untuk menemukan tujuan umum (goal) dan tujuan khusus (objektivitas) suatu organisasi atau lembagapenyelenggara pendidikan, berdasarkan dukungan informasi yang lengkap (Madjid, 2007:16). Perencanaan pembelajaran adalah proses penyusunan berbagai keputusan pembelajaran yang akan dilaksanakan dalam proses kegiatan pembelajaran untuk mencapai kompetensi pembelajaran yang telah ditetapkan. Perencanaan pembelajaran merupakan bagian integral dari komponen pembelajaran. Kegiatan perencanaan tidak boleh terlepas dari kegiatan-kegiatan yang lain dalam pembelajaran. Oleh karena itu, perencanaan pembelajaran juga harus berkaitan dengan kepentingan komponen yang terkait dengan proses pembelajaran (Wahyuni \& Ibrahim, 2012:13).

Melalui perencanaan yang baik, guru akan lebih mudah dalam melaksanakan pembelajaran dan siswa akan lebih terbantu dan mudah dalam melaksanakan pembelajaran. Perencaaan pembelajaran 
ZAHRA: Research And Tought Elmentary School Of Islam Journal Vol. (2) (2), (Agustus)(2021), (Halaman)(123-133)| 130 dikembangkan sesuai dengan kebutuhan dan karakteristik peserta didik, sekolah, mata pelajaran, dan sebagainya.Dengan perencanaan yang matang dapat mendorong guru lebih siap melakukan kegiatan pembelajaran. Oleh karena itu, setiap akan melakukan pembelajaran, guru wajib melakukan perencanaan. Dengan adanya perencanaan yang baik, maka pelaksanaan pembelajaran akan dapat berjalan lancer, terarah, dan sistematis. Hal ini dapat tercapai karena kompetensi dasar, materi pokok, indikator, pengalaman belajar, alokasi waktu, sumber, langkah-langkah pembelajaran, dan rencana penilaian telah dirumuskan dengan baik dan digambarkan dengan jelas (Madjid, 2007:22). Salah satu perencanaan pembelajaran yang penting bagi guru adalah Rencana Pelaksanaan Pembelajaran. Setiap guru dituntut untuk bia merancang atau merencanakan pembelajaran sebelum proses pembelajaran. Dengan rencana yang bagus, tentunya pembelajaran akan berjalan dengan sistematis dan terprogram.

Rencana pelaksanaan pembelajaran (RPP) adalah rencana yang menggambarkan prosedur dan pengorganisasian pembelajaran untuk mencapai satu kompetensi dasar yang ditetapkan dalam standar isi dan dijabarkan dalam silabus. RPP merupakan persiapan yang harus dilakukan guru sebelum mengajar. Persiapan disini dapat diartikan persiapan tertulis maupun persiapan mental, situasi emosional yang ingin dibangun, lingkungan belajar yang produktif termasuk meyakinkan pembelajar untuk mau terlibat secara penuh dalam proses pembelajaran yang telah direncanakan (Kunandar, 2016).

Rencana pelaksanaan pembelajaran (RPP) menjadi komponen penting dalam perangkat pembelajaran guru. Guru wajib menyusun RPP agar pembelajaran lebih terarah dalam mencapai tujuan sesuai indicator yang dikembangkan. Secara khusus, RPP dikembangkan dari silabus untuk mengarahkan pembelajaran agar mencapai Kompetensi Dasar secara efektif. Pada hakikatnya penyusunan RPP bertujuan merancang pengalaman belajar siswa untuk mencapai tujuan pembelajaran.Alasan penting membuat RPP yaitu dapat menolong guru untuk memikirkan pelajaran sebelum pelajaran itu diajarkan sehingga kesulitan belajar dapat diramalkan dan jalan keluarnya dapat dicari. Guru dapat mengorganisasi fasilitas, perlengkapan, alat bantu pengajaran, waktu da nisi dalam rangka untuk mencapai tujuan belajar seefektif mungkin serta menghubungkan tujuan dan prosedur kepada tujuan keseluruhan dari mata pelajaran yang diajarkan (Mulyasa, 2007:1)

Kebijakan baru terkait penyusunan RPP telah dikeluarkan oleh Menteri Pendidikan dan Kebudayaan, Nadiem Makarim.Kebijakan baru tersebut berupa penyederhanaan RPP, dengan mempertimbangkan prinsip efisien, efektif, dan berorientasi pada peserta didik.Efisien berarti penulisan RPP dilakukan dengan tepat dan tidak menghabiskan banyak waktu dan tenaga. Efektif artinya penulisan RPP untuk mencapai tujuan pembelajaran. Sedangkan berorientasi pada peserta didik berarti penulisan RPP dilakukan dengan mempertimbangkan kesiapan, ketarikan, dan kebutuhan belajar peserta didik di kelas (Mitra kuliah, 2020)

Berdasarkan Surat Edaran Kementerian Pendidikan dan Kebudayaan Nomor 14 Tahun 2019 tentang Penyederhanaan Rencana Pelaksanaan Pembelajaran dinyatakanbahwa, menindaklanjuti 
ZAHRA: Research And Tought Elmentary School Of Islam Journal Vol. (2) (2), (Agustus)(2021), (Halaman)(123-133)| 131 Peraturan Menteri Pendidikan dan Kebudayaan terkait denganpelaksaaaan kurikulum 2013, dinyatakan,

1. Penyusunan Rencana Pelaksanaan Pembelajaran (RPP) dilakukan dengan prinsipefisien, efektif, dan berorientasi pada murid.

2. Bahwa dari 13 (tiga belas) komponen RPP yang telah diatur dalam Peraturan MenteriPendidikan dan Kebudayaan Nomor 22 Tahun 2016 tentang Standar Proses Pendidikan Dasar dan Menengah, yang menjadi komponen inti adalah tujuan pembelajaran,langkahlangkah (kegiatan) pembelajaran, dan penilaian pembelajaran (assessment)yang wajib dilaksanakan oleh guru, sedanngkan komponen lainnya bersifat pelengkap.

3. Sekolah, kelompok guru mata pelajaran sejenis dalam sekolah, Kelompok Kerja Guru/Musyawarah Guru Mata Pelajaran (Mapel) (KKG/MGMP), dan individu guru secara bebas dapat memilih, membuat, menggunakan, dan mengembangkan format RPP secara mandiri untuk sebesar-sebesarnya keberhasilan belajar murid.

Adapun RPP yang telah dibuat tetap dapat digunakan dan dapat pula disesuaikandengan ketentuan sebagaimana dimaksud pada angka 1, 2, dan 3.Dengan demikian jelas, bahwa pada kebijakan Menteri Pendidikan danKebudayaan yang sekarang, menyatakan dalam RPP dikenal komponen inti RPP yakni(1) tujuan pembelajaran, (2) langkah-langkah (kegiatan) pembelajaran, dan, (3) penilaianpembelajaran (assessment), sedangkan 10 komponen lainnya disebut komponenpenunjang. Namun demikian, suatu kebijakan tentunya akan ada penyesuaian dari waktu ke waktu (Surat edaran mentri, 2019)

Pelajaran IPS di SD mengajarkan konsep konsep esensial Ilmu Sosial untuk membentuk subjek didik menjadi warga negara yang baik. Istilah IPS mulai digunakan secara resmi di Indonesia sejak tahun 1975 adalah istilah Indonesia untuk social studies di Amerika. Kita mengenal beberapa istilah seperti ilmu sosial studi sosial dan ilmu pengetahuan sosial. Ilmu sosial adalah ilmu yang berkenaan dengan manusia dalam konteks sosial dengan kata lain semua bidang ilmu yang mampu mempelajari manusia sebagai salah satu anggota dari masyarakat secara luas (Susanto, 2014:7).

IPS tidak lain adalah mata pelajaran atau mata kuliah yang mempelajari kehidupan sosial yang kajiannya mengintegrasikan bidang-bidang Ilmu Sosial dan humaniora dengan kata lain kajian-kajian IPS sangat luas melalui berbagai macam pendekatan pendekatan interdisipliner yang saling berkaitan dengan kehidupan sosial manusia. Ilmu pengetahuan sosial (IPS) adalah program pendidikan yang memilih bahan pendidikan dari disiplin ilmu ilmu sosial dan ilmu pendidikan sejarah yang diorganisir dan disajikan secara ilmiah dan psikologis untuk tujuan pendidikan yang berdasarkan Pancasila dan kebudayaan Indonesia.

Salah satu tujuan pembelajaran IPS di SD adalah mengembangkan pengetahuan dan pemahaman konsep-konsep IPS yang bermanfaat dan dapat diterapkan dalam kehidupan sehari-hari.Perencanaan pembelajaran IPS di SD telah diupayakan agar mencapai tujuan yang diharapkan dan hasil belajar yang diperoleh siswa pada materi tersebut. Hasil penelitian mengenai kebijakan baru terkait 
ZAHRA: Research And Tought Elmentary School Of Islam Journal Vol. (2) (2), (Agustus)(2021), (Halaman)(123-133)| 132 penyusunan RPP yang telah dikeluarkan oleh Menteri Pendidikan dan Kebudayaan menjadi bahan pertimbangan peneliti untuk membandingkan Rencana Pelaksanaan Pembelajaran yang beredar di internet dengan milik Guru SDN Tlambah 2 didasarkan pada bukti fisik RPP 1 lembar. Hasilnya adalah RPP 1 lembar yang beredar di internet dengan yang dimiliki guru tesebut telah sesuai dengan berdasarkan Surat Edaran Kementerian Pendidikan dan Kebudayaan (Kemendikbud) Nomor 14 Tahun 2019 tentang Penyederhanaan Rencana Pelaksanaan Pembelajaran.

Temuan di atas sesuai dengan teori tentang keputusan situasional yaitu keputusan yang diambil oleh guru ketika merencanakan pembelajaran atau menyusun RPP. Pada saat menyusun Rencana Pelaksanaan Pembelajaran guru mempertimbangkan banyak faktor untuk mencapai tujuan pembelajarannya, dan faktor-faktor tersebut saling berkaitan satu dengan yang lainnya.Kemampuan untuk membuat keputusan situasional juga merupakan salah satu kompetensi guru. Oleh karena itu, guru wajib mengetahui dan menguasai keterampilan pengambilan keputusan tersebut (Wardani : 2006).

Dapat disimpulkan dari penelitian ini bahwa RPP merupakan panduan guru di dalam kelas tetapi bukan merupakan aturan kaku yang harus selalu diikuti. Dari pihak guru, guru harus menguasai kompetensi profesional yang meliputi perencanaan sampai pelaksanaan pembelajaran di kelas.Guru juga memikirkan dampak perencanaan sampai pengajarannya pada pihak siswa. Oleh karena itu, guru dituntut untuk peka terhadap respon siswa. Yang terakhir, guru harus mempertanggungjawabkan tugas dan tanggungjawab pelaksanaan pembelajarannya kepada pihak sekolah. Tingkat penerapan RPP yang disusun guru dengan pelaksanaan pembelajaran di kelas akan terlihat kesesuaian perencanaan dengan pelaksanaan. Diharapkan guru menulis RPP dengan jelas dan rinci sehingga meminimalkan hal-hal yang tidak terantisipasi.

\section{Kesimpulan}

Berdasarkan hasil dan pembahasan, maka kesimpulan yang dapat diambil sebagai berikut. RPP merupakan persiapan yang harus dilakukan guru sebelum mengajar. Guru wajib menyusun RPP agar pembelajaran lebih terarah dalam mencapai tujuan sesuai indikator yang dikembangkan. Pada hakikatnya penyusunan RPP bertujuan merancang pengalaman belajar siswa untuk mencapai tujuan pembelajaran. Kebijakan baru terkait penyusunan RPP telah dikeluarkan oleh Menteri Pendidikan dan Kebudayaan, yaitu berupa penyederhanaan RPP, dengan mempertimbangkan prinsip efisien, efektif, dan berorientasi pada peserta didik.RPP 1 lembar yang beredar di internet dengan yang dimiliki Guru SDN Tlambah 2 telah sesuai dengan berdasarkan Surat Edaran Kementerian Pendidikan dan Kebudayaan Nomor 14 Tahun 2019 tentang Penyederhanaan Rencana Pelaksanaan Pembelajaran.

Ilmu pengetahuan sosial (IPS) adalah program pendidikan yang memilih bahan pendidikan dari disiplin ilmu ilmu sosial dan ilmu pendidikan sejarah.Salah satu tujuan pembelajaran IPS di SD adalah mengembangkan pengetahuan dan pemahaman konsep-konsep IPS yang bermanfaat dan dapat diterapkan dalam kehidupan sehari-hari.Perencanaan pembelajaran IPS di SD telah diupayakan agar mencapai tujuan yang diharapkan dan hasil belajar yang diperoleh siswa pada materi tersebut. 


\section{Daftar pustaka}

Ahmadi, Rulam. (2016). Metode Penelitian Kualitatif. Yogyakarta:Ar-Ruzz Media.

Edukasi Belajar Bersama. (2013) RPP untuk kelas 5 tema 7 kurikulum. Retrieved https://www.websiteedukasi.com/rpp-kelas-5-tema-7-kurikulum-2013.html

Gunawan, G., \& Asrifan, A. (2020). Penerapan Kerja Kelompok Kegiatan MGMP Guru Ekonomi dalam Menyusun RPP untuk Meningkatkan Kompetensi Pedagogik. Celebes Education Review, 2(1), 31-36. https://doi.org/10.37541/cer.v2i1.318

Hamalik, Umar. (2005). Kurikulum dan Pembelajaran. Jakarta: Bumi Aksara.

Herdiyansyah, Haris. (2013). Wawancara, Observasi, dan Focus Group Sebagi Instrumen Penggalian Data Kualitatif.Jakarta:Rajawali.

Kunandar, (2011).Guru Profesional (Implementasi Kurikulum Tingkat Satuan Pendidikan dan Sukses dalam Sertifikasi Guru).Jakarta: Raja Grafindo Persada.

Majid, Abdul. (2007). Perencanaan Pembelajaran: Mengembangkan Standar Kompetensi Guru. Bandung: Remaja Rosda Karya.

Mitra kuliah dalam edukasi. (2019) Contoh RPP Satu lembar Untuk SD/MI Semester 2 Terbaru pada 2020 Yang Sesuai Dengan Edaran Kemendikbud. Retrieved from https://www.mitrakuliah.com/m/2020/01/14/contoh-rpp-satu-lembar-untuk-sd-mi-semester2-terbaru-2020-sesuai-surat-edaran-kemendikbud-n0-14-tahun-2019/

Mulyasa.(2007). Kurikulum Tingkat Satuan pendidikan. Bandung: Remaja Rosda Karya.

Munchen, T. U. (2018). Model Pembelajaran IPS Talking Stick pada siswa kelas VI Sekolah Dasar Takengon. E-Conversion - Proposal for a Cluster of Excellence, 1(3), 29-50.

Siska, Yula. (2016). Konsep Dasar IPS untuk Sd/MI. Yogyakarta: Garudhawaca.

Suharsaputra, Uhar. 2012. Metode Penelitian Kualitatif dan Tindakan. Bandung: PT Refika Aditama.

Susanto, Ahmad. (2014). Pengembangan Pembelajaran IPS. Jakarta: Prenada Media Group.

Surat Edaran Kementrian Pendidikan dan Kebudayaan Nomor 14 Tahun 2019 tentang Penyederhanaan Rencana Pelaksanaan Pembelajaran.

Saharuddin, M. (2020). Strategi Pembelajaran IPS : Konsep dan Aplikasi.

Wahyuni, Sri dan Ibrahim, Abd. S. (2012). Perencanaan Pembelajaran Bahasa Berkarakter. Malang: Refika Aditama.

Wardani, I.G.A.K. (2006). Pengambilan Keputusan dalam Layanan Ahli Pembelajaran. Universitas Terbuka: Pusat Antar Universitas (PAU), Naskah belum diterbitkan. Naskah untuk Lokakarya Penyempurnaan Kurikulum Program Pekerti/AA.

Yaniawati, Poppy. (2020). Penelitian Studi Kepustakaan. Bandung: Lingkungan Dosen FKIP Unpas. 